\title{
Deoxyribonucleic Acid Homology in Anaerobic Lactobacilli and in Possibly Related Species
}

\author{
M. ELISABETH SHARPE AND F. DELLAGLIO
}

National Institute for Research in Dairying, Shinfield, Reading RG2 9AT, England, and Istituti di Microbiologia Agraria e Tecnica e Microbiologia Lattiero-casearia, Facolta di Agraria, Universita Cattolica del Sacro Cuore, Piacenza, Italy

The deoxyribonucleic acid (DNA) relationships among strains of the anaerobic Lactobacillus species $L$. ruminis and $L$. vitulinus, other lactobacilli with mesodiaminopimelic acid in the cell wall peptidoglycan, and $L$. jensenii were studied by DNA-DNA hybridization experiments. The DNA of strains assigned to $L$. ruminis had a high degree of homology. However, strains which have been assigned to $L$. vitulinus were genotypically heterogenous, three different unrelated groups being included. There was a very low level of homology between these two species and between them and L. plantarum subsp. mobilis, L. plantarum, and L. jensenii.

Two species of anaerobic lactobacilli, Lactobacillus ruminis and $L$. vitulinus, both containing meso-diaminopimelic acid (meso-DAP) in the peptidoglycan of the cell wall, have been described (8). To confirm that these taxa, designated as species by their phenotypic characteristics, are also genotypic species and to investigate their possible relationships to other lactobacilli with some similar characteristics, deoxyribonucleic acid (DNA) hybridization studies were made.

\section{MATERIALS AND METHODS}

Bacterial strains. The strains of lactobacilli examined are listed, with the references to published descriptions, in Table 1 . One of the strains (194e) isolated from faeces of a human adult by Reuter (6) and described as L. catenaforme (ATCC 25644) was recently reidentified as a strain of $L$. ruminis by $L$. V. Holdeman (personal communication). L. vitulinus GA1, designated by Bryant (1) as Lactobacillus sp. GA1, was isolated by him as part of the predominant microflora of the rumen of an adult cow fed fresh alfalfa and described (1) as identical to strain T185 (2) except that lactose was not fermented.

Cultures were grown in MRS broth (5). Physiological tests were done as described (8). Detection of meso-DAP in the cell walls was by the method of Schleifer and Kandler (7). For the labeling of DNA and determination of DNA homology, the methods of Dellaglio et al. (4) were used.

\section{RESULTS AND DISCUSSION}

Characteristics of lactobacilli strains 194e and GA1. Meso-DAP was detected in the cell walls of both strains. Strain 194e had the same sugar fermentation patterns, growth temperatures, and physiological characteristics as $L$. ruminis (8), and formed (+)-lactic acid. It differed from $L$. ruminis, however, in being nonmotile. Strain GA1 had similar characteristics to strains of $L$. vitulinus, was nonmotile, and formed $\mathbf{D}(-)$-lactic acid. However, it did not ferment lactose, as Bryant also observed (1). It was assigned to the species $L$. vitulinus.

DNA hybridization. Table 1 shows the results of DNA-DNA hybridization experiments with strains of the different species of lactobacilli.

Strains assigned to the species $L$. ruminis were homologous genotypically as well as phenotypically. All four strains were closely related to each other, with 95 to $100 \%$ homology. Strain 194e, with a $95 \%$ homology to the other three strains, was the only nonmotile strain. There was no relationship with $L$. vitulinus. Previously it was noted (8) that the motile $L$. plantarum subsp. mobilis had some characteristics in common with $L$. ruminis, including motility, presence of meso-DAP in the wall, similar guanine plus cytosine $(G+C)$ ratios, and type of lactic acid formed, although there were other differentiating characters such as sugar fermentation patterns and ability to grow aerobically. The present work shows a low genetic homology (only 13\%), indicating that these organisms are not the same or closely related species.

However, there was little genetic homology between the strains assigned to the species $L$. vitulinus. The strains appear to fall into three different genotypes. Strains T185 and GA1 are closely related (90 to $100 \%$ homology). This agrees with Bryant's (2) observation that these two strains are very similar. Strain B62 appears to be unrelated to these two strains, with a homology of only $13 \%$ to T185. Bryant et al. 
TABLE 1. DNA homology relationships among strains of anaerobic lactobacilli and other lactobacilli

\begin{tabular}{|c|c|c|c|c|c|c|c|c|}
\hline \multirow{2}{*}{ Strain } & \multirow{2}{*}{$\begin{array}{l}\text { Refer- } \\
\text { ence }\end{array}$} & \multirow{2}{*}{$\begin{array}{l}\text { L. rum- } \\
\text { inis RF1 }\end{array}$} & \multicolumn{3}{|c|}{ L. vitulinus } & \multirow{2}{*}{$\begin{array}{c}\text { L. jensenii } \\
\text { ATCC } 25258\end{array}$} & \multirow{2}{*}{$\begin{array}{c}\text { L. plan- } \\
\text { tarum } \\
\text { ATCC } 14917\end{array}$} & \multirow{2}{*}{$\begin{array}{l}\text { L. plantarum } \\
\text { subsp. mobilis } \\
\quad 20-23\end{array}$} \\
\hline & & & $\mathrm{T} 185$ & CL1 & CL13 & & & \\
\hline \multicolumn{9}{|l|}{ Lactobacillus ruminis } \\
\hline $\mathrm{RF}^{a}{ }^{a}$ & 8 & 100 & 8 & 5 & 4 & 14 & 5 & 6 \\
\hline RF2 & 8 & 100 & 8 & 3 & $\mathrm{ND}^{b}$ & 5 & 16 & ND \\
\hline RF3 & 8 & 101 & 12 & 7 & ND & ND & ND & ND \\
\hline $194 \mathrm{e}$ & 6 & 95 & 20 & 0 & ND & 11 & 7 & ND \\
\hline \multicolumn{9}{|l|}{ L. vitulinus } \\
\hline $\mathrm{T}_{185^{a}}(\mathrm{RL} 2)$ & 2,8 & 16 & 100 & 22 & 10 & 10 & 8 & 10 \\
\hline GA1 & 1,2 & 0 & 90 & 15 & ND & ND & ND & ND \\
\hline B62 (RL1) & 2,8 & 14 & 13 & 18 & ND & 8 & 6 & ND \\
\hline CL1 & 8 & 0 & 11 & 100 & 102 & 3 & 8 & ND \\
\hline CL13 & 8 & 4 & 10 & 102 & ND & ND & ND & ND \\
\hline L. jensenii ATCC 25258 & 8 & 8 & 14 & 0 & & 100 & 6 & 13 \\
\hline L. plantarum ATCC 14917 & & 12 & 17 & 15 & & 9 & 100 & 10 \\
\hline L. plantarum ATCC 10776 & & ND & ND & ND & & ND & $57^{c}$ & 17 \\
\hline L. pentosus ATCC 8041 & 4 & ND & ND & ND & & ND & $40^{c}$ & 1 \\
\hline \multirow{2}{*}{$\begin{array}{l}\text { L. plantarum subsp. mob- } 8 \\
\text { ilis } 20-23\end{array}$} & & 13 & 17 & ח & & 14 & 5 & 100 \\
\hline & & 10 & 17 & ND & & & & \\
\hline
\end{tabular}

a Type strains.

${ }^{b}$ ND, Not done.

c Data from Dellaglio et al. (4).

(2) considered T185 and B62 to belong to two different groups, $+\mathrm{R} 3$ and $+\mathrm{R} 4$, respectively, on the basis that the latter group of strains grew at $22^{\circ} \mathrm{C}$, produced a very small amount of gas from glucose, fermented trehalose, and had a different morphology from the former. In addition, we found (8) that the cell wall sugar components were different, glucose, rhamnose, galactose, and galactosamine being detected in B62, but only glucose being detected in T185. This was not then regarded as sufficient for species differentiation and we considered that these strains should be regarded as different subspecies of $L$. vitulinus. However, the very low level of genetic homology between the two confirms Bryant's original opinion (2) of two divergent species. As strain T185 was designated the type strain (8), it must continue to bear the species name $L$. vitulinus, whereas strain B62 should be excluded from the species.

Strains CL1 and CL13 were closely related to each other by DNA hybridization (100 to $102 \%$ homology) but not to either T185 or to B62. Strains T185, B62, and CL13, on which the more detailed studies were done, were previously grouped as a phenotypic species on the basis of their similar physiological characteristics, similar low levels of ammonia nitrogen in the cell wall peptidoglycan compared with other anaerobic lactobacilli, and similar $\mathrm{G}+\mathrm{C}$ ratios of $34.9,34.4$, and $37.1 \mathrm{~mol} \%$ respectively. From our present data it must be concluded, however, that strains originally assigned to $L$. vitulinus form a genotypically heterologous group, containing strains belonging to three different species, $L$. vitulinus (type strain T185) and two others. More work is required before these species represented by B62 and CL1 + CL13 can be further classified.

Differences between strains T185, B62, CL1, and $L$. jensenii (i.e., the latter has the D-Asp-Llysine type wall peptidoglycan, grows aerobically, and hydrolyzes arginine) are confirmed by the lack of genetic relationships ( 3 to $10 \%$ ) in spite of similar characteristics between the two species (type of lactic acid formed, fermentation pattern, and $\mathrm{G}+\mathrm{C}$ ratios).

Strains of $L$. plantarum, another meso-DAPcontaining species, were included in this work to see if they were related to the motile $L$. plantarum subsp. mobilis. As recent DNA homology studies (4) indicated the presence of two groups within $L$. plantarum, data on representative strains of both groups were included. However, none of the three strains appeared to be related to L. plantarum subsp. mobilis .

Apart from the genotypic homogeneity of strains assigned to the species $L$. ruminis, the present results generally indicate an absence of relationships among the strains of lactobacilli studied. It is evident, as previous workers have found, that similar fermentation patterns and other physiological characteristics, the presence of meso-DAP in the cell wall peptidoglycan, and similar $\mathrm{G}+\mathrm{C}$ ratios are not indicators of a genetic relationship. The position of the strains assigned to the species $L$. vitulinus, on phenotypically recognizable characters, must await further investigations.

It is of interest that $L$. ruminis $194 \mathrm{e}$ was 
isolated as part of the majority flora from the intestinal tract of an adult human (6) and that similar strains have been found frequently in the gut of both children and adults, indicating the presence of this organism in the human intestine as well as in the bovine rumen.

\section{ACKNOWLEDGMENT}

We wish to thank B. A. Phillips and E. Bosi for skilled technical assistance.

\section{REPRINT REQUESTS}

Address reprint requests to: Dr. M. E. Sharpe, University of Reading, National Institute for Research in Dairying, Shinfield, Reading RG2 9AT, England.

\section{LITERATURE CITED}

1. Bryant, M. P. 1959. Bacterial species of the rumen. Bacteriol. Rev. 23:125-153.

2. Bryant, M. P., N. Small, C. Bouma, and I. Robinson. 1958. Studies on the composition of the ruminal flora and fauna of young calves. J. Dairy Sci. 41:1747-1767.

3. Dellaglio, F., V. Bottazzi, and L. D. Trovatelli. 1973. Deoxyribonucleic acid homology and base composition in some thermophilic lactobacilli. J. Gen. Microbiol. 74:289-297.

4. Dellaglio, F., V. Bottazzi, and M. Vescovo. 1975. Deoxyribonucleic acid homology among Lactobacillus species of the subgenus Streptobacterium Orla-Jensen. Int. J. Syst. Bacteriol. 25:160-172.

5. de Man, J. C., M. Rogosa, and M. E. Sharpe. 1960. A medium used for the cultivation of lactobacilli. J. Appl. Bacteriol. 23:130-135.

6. Reuter, G. 1975. Composition of the microflora of the human small intestine and the behaviour of some microorganisms after oral intake. Proc. 1st Intersect. Congr. Japan 1974 2:327-339.

7. Schleifer, K. H., and O. Kandler. 1972. Peptidoglycan types of bacterial cell walls and their taxonomic implications. Bacteriol. Rev. 36:407-477.

8. Sharpe, M. E., M. J. Latham, E. I. Garvie, J. Zirngibl, and O. Kandler. 1973. Two new species of Lactobacillus isolated from the bovine rumen, Lactobacillus ruminis sp. nov. and Lactobacillus vitulinus sp. nov. J. Gen. Microbiol. 77:37-49. 